Portland State University

PDXScholar

$1-1-2013$

\title{
Building Stories: Modernity, Socialization and Failure in Works of Franz Kafka and Hannah Arendt
}

Chris Carpenter

Portland State University

Follow this and additional works at: https://pdxscholar.library.pdx.edu/honorstheses

Let us know how access to this document benefits you.

\section{Recommended Citation}

Carpenter, Chris, "Building Stories: Modernity, Socialization and Failure in Works of Franz Kafka and Hannah Arendt" (2013). University Honors Theses. Paper 8.

https://doi.org/10.15760/honors.8

This Thesis is brought to you for free and open access. It has been accepted for inclusion in University Honors Theses by an authorized administrator of PDXScholar. Please contact us if we can make this document more accessible: pdxscholar@pdx.edu. 


\title{
Building Stories:
}

Modernity, Socialization, and Failure in the Works of Franz

\author{
Kafka and Hannah Arendt
}

By

Chris Carpenter

A thesis submitted in partial fulfillment

of the requirements for the

BACHELOR OF ARTS WITH HONORS

in

ENGLISH

Thesis Supervisor: Jennifer Ruth

Portland State University

2013 


\section{Table of Contents}

I.) Introduction 3

II.) Public, Private, Social 12

III.) Labor and Work 26

IV.) The Archimedean Point 42

$\begin{array}{ll}\text { Bibliography } & 61\end{array}$ 


\section{I.) Introduction}

Modernity, for Hannah Arendt, is primarily a matter of loss: authority, certainty, tradition, and the possibility for meaningful action that can only occur in a public sphere in the full view of equals. The modern age is coeval with the rise of society - the private realm of "housekeeping, its activities, problems, and organizational devices," ${ }^{1}$ which has mixed with the public so completely as to make them indistinguishable. The basic biological needs of humanity, once relegated to the privacy of the household and deemed unworthy of true political discussion, have become part and parcel with the political process as such. Aristotle's zoon politikon has become an animal laborans, bringing his labor into the forefront of public discussion, indeed making it the topic for public discussion. This shift has been made possible, in part, by the rise of reason, rationality, and science, a development which considers man as part of a cosmic machine operating under universal laws. The collection of equals that characterized the Greek polis has become a collection of bureaucrats, placing their faith, as it were, in the dictums of statistics and "behavioral sciences," which "aim to reduce man as a whole, in all his activities, to the level of a conditioned and behaving animal." 2

It cannot be doubted that Franz Kafka is a modern writer. Something about the "tremendous world I have inside my head" that Kafka related to us through his novels, stories, and parables has managed to retain its resonance almost 100 years after their composition. It is a world where man must bow his head, where tradition is inscribed with a "sickness," and the certainty allowed by appeals to a higher power - God, the King, the

\footnotetext{
${ }^{1}$ Arendt, The Human Condition 38 (HC)

${ }^{2}$ HC 45
} 
Platonic eidos -have crumbled under the onslaught of modernity: "Nowhere in Kafka does there glimmer the aura of the infinite idea; nowhere does the horizon open." 3 This is a world we can experience in any number of everyday situations, from going to the DMV to hearing physicists explain our world in terms of quarks and bosons, numbers and symbols. It seems completely outside the realm of common human experience, completely irrational, but we are told that this is the way it is, and we believe it because it seems like there can be no alternative. The adjective for this kind of experience, "kafkaesque," has entered common parlance. Frederick Karl describes his conception of the word:

What's Kafkaesque is when you enter a surreal world in which all your control patterns, all your plans, the whole way in which you have configured your own behavior, begins to fall to pieces, when you find yourself against a force that does not lend itself to the way you perceive the world. You don't give up, you don't lie down and die. What you do is struggle against this with all of your equipment, with whatever you have. But of course you don't stand a chance. That's Kafkaesque. ${ }^{4}$

Arendt was no stranger to Kafka's works. After coming to America to flee the Nazis, she worked as an editor at Schocken Books, the imprint most responsible for exposing the English-speaking world to Kafka. She also wrote an essay on Kafka for The Partisan Review in 1944, establishing herself as one of his earliest critics. The prologue to Between Past and Future contains a detailed reading of Kafka's parable "He." She leads the final chapter in The Human Condition with an aphorism from Kafka.

\footnotetext{
${ }^{3}$ Adorno p. 246

${ }^{4}$ Edwards
} 
The extent of Kafka's influence on Arendt's conception of modernity is difficult to pin down. Most of the existing scholarship focuses on her account of totalitarianism, and places Kafka in the role of prophet, predicting real phenomena that wouldn't occur until after his death. In her only work focused exclusively on Kafka, Arendt deems him a builder of "blueprints," models that are "the product of thinking rather than of mere sense experience." ${ }^{5}$ Kafka's "unreality," the sense in which his works clearly describe a world that is not explicitly ours, "expose the naked structure of events" through the purely mental activity of imagination. Kafka did not look around him and see the birth pangs of Hitler and Stalin, but he did see the underlying conditions that would eventually lead to very real atrocities, though he could not have known it at the time. Kafka's vision, so to speak, was exemplary for its ability to see the unseen and pass over blindly that which appeared most readily. ${ }^{6}$ His parables are organized around an "incident" like "rays of light which, however, do not illuminate its outward appearance but possess the power of $\mathrm{X}$ rays to lay bare its inner structure." 7 This incident is the moment where past and future converge, the individual moment of lived experience.

In her essay, Arendt attempts to read a kind of hope into the novels, a capacity for resistance against a world that seeks to dispense with the human. She asserts that Kafka "wanted to build up a world in accordance with human needs and human dignities, a world where man's actions are determined by himself and which is ruled by his laws and not by

\footnotetext{
${ }^{5}$ Arendt, "Kafka: A Revaluation" pp. 76-77. (KAR)

6 "The world of those realities that were important for him was invisible." Max Brod, quoted in Benjamin, p. 121

7 Between Past and Future, pp. 7 (BPAP)
} 
mysterious forces emanating from above or from below." 8 This world is populated by characters that are models of "the 'common man' as an ideal of humanity... the motor of his activities is good will, in contrast to the motor of society with which he is at odds, which is functionality." ${ }^{9}$ Arendt sees a kind of kindred spirit in Kafka, and wants to reconcile him with her project, which explores the possibility for meaningful action in an age that always seems to preclude it. Figures like Joseph K. in The Trial and K. in The Castle are exemplary, in her analysis, for exposing the "naked structure" of modernity in all its shoddiness and lack of feeling. They struggle against it in an attempt to bring about a more humane way of living.

Arendt is famous for a prose style that has been described as "literary political theory," 10 or what she herself called simply "my old fashioned storytelling." This methodology encourages readers to form their own response to her empirical research, taking into account a myriad of different vantage points that she lays out over the course of a "story." Part of her critique of modernity is the cessation of this openness, the sense that in the modern world meaning is prescribed a priori as part of necessary processes beyond our control, by a force that appeals to nothing and no one. History has become the progress of "an inevitable superhuman law" 11 embodied by the workings of a machine in which humans are caught. By emphasizing the human element of history, Arendt invites us, or rather demands of us, to make judgments for ourselves. Rather than presenting her accounts of modern phenomena as an objective report of the facts, Arendt discloses her

\footnotetext{
${ }^{8}$ KAR 80

${ }^{9}$ KAR 76

${ }^{10}$ Dossa, 1

11 KAR 74
} 
own subjectivity and compels us to imagine (or recall) these phenomena as lived experience. "She writes to move her audience to engage with her in thinking 'what we are doing."” 12

This methodology makes it easier to account for her reading of Kafka, and its potential faults. His works are made to fit into the story she is trying to tell, one that articulates a fall brought about by the alienating effects of modernity. Arendt struggles against this fall, and she reads Kafka as a figure engaged in the struggle. "He wanted to build up a world in accordance with human needs and human dignities, a world where man's actions are determined by himself and which is ruled by his laws and not by mysterious forces emanating from above or from below." 13 This approach is useful for thinking through Arendt's program, but few critical statements could be more misleading with regards to the Kafka text. One problem is bad data: she did not know that Amerika, Kafka's first and most optimistic novel, was actually his last and thus reads his work as a progression from pessimism (The Trial and The Castle) to hope for a better world. Another seems to be simple and willful misreading. Many critics before and after Arendt have tried to read Kafka optimistically, but it is extremely dubious to claim that the world Kafka "wanted to build up" has anything to do with greater human agency. Joseph K. is executed without gaining a modicum of truth or meaning out of his whole experience. K. in The Castle withers away of exhaustion after endless thwarted attempts to reach the titular fortress, and is deprived the opportunity to live a "normal" life in this very strange village. All of

\footnotetext{
12 I owe this quote, and much of the thought laid out in the preceding paragraph, to Lisa Disch's essay "More Truth than Fact: Storytelling as Critical Understanding in the Writings of Hannah Arendt" 13 KAR 80
} 
Kafka's fiction ends in similarly morbid fashion, if it has anything that could be considered an "ending" at all. ${ }^{14}$

Like Arendt, Kafka is engaged in a struggle, but it is one with no clear goal. There is no light at the end of the tunnel. As Walter Sokel notes, "Kafka, in writing, does not seem to have a preconceived meaning, a fixed intention, in his mind." 15 It seems Kafka wrote simply because he had too, because it was the only thing that compelled him towards living - not to the mention the fact that he was preternaturally gifted, to an almost absurd degree. ${ }^{16}$ Nevertheless, it is unlikely that anyone in history has explored more intimately than Kafka the question "why write?" An almost endless number of pages in his diary and letters probe the meaning, the impetus for writing as such. On the one hand it was an "impossibility," 17 and on the other it was an absolute necessity. ${ }^{18}$ We can, however, note with only slight hesitance that he did not write to facilitate change, to diagnose an illness that needed correction. He certainly observed the "sickness of tradition," ${ }^{19}$ but he saw it with the eyes of someone immersed in a swamp without beginning or end; there is no cure. While Arendt reads the Kafka "hero" as engaged in a struggle, the characters themselves all recognize the futility of their efforts, the Sisyphean nature of their labor. Far from active agents disclosing the possibility for new beginnings, for breaking out of the machine, the

\footnotetext{
14 The majority of Kafka's extant work was unpublished in his lifetime, and mostly unedited. The Trial, for instance, was a collection of fragments which Max Brod assembled as he saw fit. 15 Sokel pp. 33

${ }^{16} \mathrm{He}$, of course, knew this very well: "Every sentence I write down is already perfect." 17 "[The Jewish writers] live beset by three impossibilities: the impossibility of not writing, the impossibility of writing in German and the impossibility of writing differently, and we could add a fourth impossibility: the impossibility of writing at all."

18 "My talent for portraying my dreamlike inner life has thrust all matters into the background; my life has dwindled dreadfully, nor will it cease to dwindle. Nothing else will ever satisfy me."

19 Benjamin pp. 143
} 
characters are swept up by the "angel of history," who "turns his face to the past." 20

If Arendt's Kafka is, then, primarily useful for understanding Arendt, perhaps we may use Arendt to better understand Kafka. I would like to do this by utilizing some of the categories she explores in The Human Condition to show how both authors managed to diagnose many of the same illnesses afflicting modernity, even if they did so by different means and with different ends in mind. For Arendt this end was hope for the future, for a thinking "without bannisters," for new possibilities of action. As for Kafka, I would like to reference Walter Benjamin's letter to Gerhard Scholem in 1938, in which he makes a very strange claim:

To do justice to the figure of Kafka in its purity and its peculiar beauty one must never lose sight of one thing: it is the purity and beauty of a failure. The circumstances of this failure are manifold. One is tempted to say: once he was certain of eventual failure, everything worked out for him en route as in a dream. ${ }^{21}$

Failure, in the Benjaminian analysis, is Kafka's end, the eventual telos of his whole writing project. This is an incredibly contentious statement, and one not widely shared by Benjamin's critical descendants. ${ }^{22}$ I would like to argue that he is actually more faithful to the Kafka text than any of the more optimistic critics who followed. Failure is built into his stories in a way that is fundamental to their unfolding in time. If the stories work towards something, it is the realization that they have actually been working backwards or treading

\footnotetext{
20 Benjamin quoted in KAR 75. More on this concept in Part 3.

${ }^{21}$ Benjamin pp. 144-45

22 For Deleuze and Guattari's response to Benjamin's "failure," see Laura Penny's "Parables and Politics: How Benjamin and Deleuze \& Guattari Read Kafka"
} 
water just to stay in place. Kafka's world is, in Benjamin's terms, a "swamp world." 23 The "infinite idea" is already recognized as impossible, but the desire for it always remains. This is the way everything "works out" for him "en route as in a dream." That this desire must end in failure leads to a kind of negative revelation, "a negative achievement, a negative elimination of all significant difference between consciousness and existence." 24

By reading Kafka through an Arendtian lens, and keeping this reading duly situated within the Benjaminian teleology of failure, I think we can gain some new insights into the way modernity functions in his stories. While Arendt herself might have been a little disappointed in the pessimism such an analysis will inevitably entail, what it lacks in optimism will hopefully be made up for in faithfulness to the figure of Kafka. We must always remember that this is the man who said "there is hope - an infinite amount of hope - but not for us."

I will focus on two of Kafka's stories here, "The Burrow" and "The Great Wall of China." The narrators of both stories analyze a building process; the kind of structure attempted, the reasons for building, and the ways each project constitute the subjects involved. I choose these stories because the process of building provides a good context for connecting Kafka to Arendt's categories of the vita activa. The kind of labor involved in building them, the specific spaces they enclose, and the ambiguous goals of both projects are very modern, in that they are critiqued through a scientific/logical framework and situated within a world

${ }^{23}$ Benjamin p. 130

24 Thorlby pp. 80 
where all certainty has disappeared. Both invoke Kant's dictum "Sapere aude!" 25 and both ultimately run up against a point where the dictum fails. For the burrower, it is the intrusion of a mysterious "whistling" with no discernible position in space, an intrusion that eventually leads to the collapse of his world. All his efforts to discover the nature of this phenomenon fail. For the narrator of "The Great Wall," it is the existence of a "high command," infinitely distant from the people it rules over. The Chinese people have a maxim: "Try with all your might to comprehend the decrees of the high command, but only up to a certain point; then avoid further meditation." 26 These characters are, in a sense, caught up in the "machinery" of Enlightenment rationality, but they cannot use it to their advantage, much less understand it. I will return to this notion when I discuss the "Archimedean point," the privileged outside vantage from which one can see everything as a whole and understand it.

For all the thematic similarities, the differences in the two stories are probably more illuminating. "The Burrow" is narrated by an asocial, solipsistic animal-human hybrid concerned only with himself and his creation. "The Great Wall," on the other hand, involves an entire empire, and its narrator is concerned with the workings of a multitude. By putting the stories into a dialogue, we can gain some insight into Arendt's conception of humanity as a plurality: "... the fact that men, not Man, live on the earth and inhabit the world." 27 For Arendt this is the condition of action, "the only activity that goes on directly between men and without the intermediary of things or matter." By presenting the individual as a being driven partially by animal instincts and partially by man's rationality, as opposed to the

\footnotetext{
${ }^{25}$ Kant

${ }^{26}$ Kafka, The Complete Stories 240 (KCS)

27 HC 7
} 
population of an empire which is depicted as a kind of abstract totality, Kafka shows two different ways to think through the vita activa in the modern age, specifically in terms of the public and private. Arendt analyzes the public sphere as the space wherein the individual, freed from the conditions of necessity, may engage in politics and create something new; for Kafka as for Arendt, the conflation of public and private dismisses the individual and subjects him to the same processes of historical necessity as the population. This conflation is the "social" sphere of human existence - "the rise of housekeeping, its activities, problems, and organizational devices." 28 The only way out of this modern "machinery" appears to be the dream, attained in moments of inaction, pointing towards the impossible. The dream, in Adorno's words, "confirm[s] the reality of everything else, even if it should be that dream reality suggested periodically by passages... so agonizingly drawn out they leave the reader gasping for air." 29

\section{II.) Public, Private, Social}

For Arendt, the rise of the social is the condition of modernity, the element that most singularly distinguishes it from tradition. ${ }^{30}$ In antiquity the public and private realms were sharply delineated by several factors: the kind of activity permitted, the type of subject allowed to participate, and the particular physical space that marked the proper domain of each. The private realm was bound to the processes of necessity, the daily cares in which

\footnotetext{
${ }^{28} \mathrm{HC} 38$

${ }^{29}$ Adorno 248. Adorno is specifically referencing The Castle and Amerika here, but I think the statement holds true for Kafka's work as a whole.

30 "The emergence of the social realm, which is neither private nor public, strictly speaking, is a relatively new phenomenon whose origin coincided with the emergence of the modern age and which found its political form in the nation-state." HC 28
} 
each human being must labor in order to survive. Matters of economics and individual prosperity - material interests - were also reserved for the private because they are driven by "wants and needs," 31 and do nothing for the higher categories of activity which can only be undertaken once purely biological motives have been taken care of. This is why slaves were so crucial to the functioning of both the polis and the Roman city-state; they allowed the citizen to shrug necessity and join his equals in politics, philosophy, and the arts. "Everything merely necessary or useful is strictly excluded." ${ }^{22}$ The higher activities were not only proper to the public sphere, they were the very definition of public. Equally important was the presence of others with whom one could engage on equal footing. The private realm of the household might was the "center of strictest inequality," 33 and even the master of the house was not free when he was in it because he was still burdened with the command of others.

Every activity performed in public can attain an excellence never matched in privacy; for excellence, by definition, the presence of others is always required, and this presence needs the formality of the public, constituted of one's peers, it cannot be the casual, familiar presence of one's equals or inferiors. ${ }^{34}$

The rise of the social marked the spilling over of the private into the public, and a complete reconstitution of the organizational principles that govern and define the latter. For the ancients this structural transformation would have been unfathomable.

\footnotetext{
${ }^{31}$ Arendt notes that in antiquity even slaves could amass a respectable fortune, but this offered little consolation for their exclusion from the public sphere. HC 59

32 HC 25

${ }^{33} \mathrm{HC} 32$

${ }^{34} \mathrm{HC} 49$
} 
Participation in the public sphere was practically the whole meaning of existence, and to sully the kind of activity that it alone permitted, by freeing the tedium and banality of the household from its confines, would have seemed utterly absurd. We will discuss some of the causes for such a transformation later, but for now we need only concern ourselves with its effects.

By conflating the private and public, humanity began to consider itself en masse as a kind of conditioned animal, a population rather than a plurality. The "phenomenon of conformism" became the impetus for the concurrent rise of the social sciences, which are possible only insofar as men "unanimously followed certain patterns of behavior, so that those who did not keep the rules could be considered to be asocial or abnormal." 35 The "rules" spread to cover larger and larger swaths of people and space, aiming to assimilate everyone into a certain predictability. Perhaps most emblematic of this statistical predilection was the development of economics, which has had profound impacts on the organization of society. ${ }^{36}$ Labor, the necessary activity of sustaining life (which we will discuss further in the next part of this essay), was liberated from the private realm and given singular importance in the public discourse, and the security of it's handmaiden property - "the labour of our body and the work of our hands," in Locke's terms - ${ }^{37}$ became the overriding concern of politics. "Originally," Arendt notes, "property meant no more or less than to have one's location in a particular part of the world and therefore to belong to

\footnotetext{
${ }^{35} \mathrm{HC} 42$

${ }^{36}$ Even the term, "organization of society," already speaks volumes to the kind of change Arendt is articulating.

37 HC 111
} 
the body politic..." ${ }^{38}$ Only with the rise of the social did the interior of this private domain and its attendant concept of ownership become a matter for legislation and intervention in the public. ${ }^{39}$

The impact of humankind's socialization is stamped all over the work of Kafka. The depth of his insight into the ways that it shapes and confounds the individual is one his most scrutinized (and celebrated) contributions to modern literature. To see the effects of this, we need look no further than the "hero" of The Trial, Joseph K., consumed and destroyed by "a great organization... which not only employs corrupt wardens, stupid inspectors, and examining magistrates... but also has at its disposal a judicial hierarchy of high, indeed the highest, rank, with an indispensible retinue of servants, clerks, police and other assistants, perhaps even hangmen." ${ }^{40}$ Men defined by jobs, endless hierarchies which obey arbitrary laws, hawk-eyed attention paid to private activities and desires, the inexorable progression of processes which seem completely outside human control. Totalitarianism, the most atrocious example of socialization taken to its extreme, appears latent in Kafka's worldview, as Arendt herself asserts in "A Revaluation." ${ }^{41}$ Moreover, the effects of modern processes like capitalism and self-alienation achieve expression in stories like "The Metamorphosis" that are the non plus ultra of modern human experience, giving voice to "socially forbidden feelings and thoughts," while also revealing a "censoring, concealing, and thus repressive side that made the rebellion they tried to express

\footnotetext{
${ }^{38} \mathrm{HC} 61$

${ }^{39}$ An important part of Arendt's analysis, which we will not delve into here, consists of the rise of so-called "market forces" and the commodification of almost everything that can be produced. I leave this out mainly because it is far too large a topic for the scope of the present investigation, and also because the two Kafka stories I've chosen have relatively little to do with exchange, productivity, and other concepts related to capital.

40 Quoted in KAR 70

41 For an analysis of Kafka's influence on The Origins of Totalitarianism, see Danoff
} 
unrecognizable to consciousness." ${ }^{42}$ Arendt is quite right when she notes

Only the reader for whom life and the world and man are so complicated, of such terrible interest, that he wants to find out some truth about them and who therefore turns to story tellers for insight into experiences common to us all may turn to Kafka..." 43

"The Great Wall of China" provides a different perspective on the relationship between public, private and social. The story has the form of a "report," an analysis of structures and conditions rather than a narrative relation of events unfolding over linear time. We know that the narrator himself has a particular vantage, a village in the southeast of China, and has only anecdotal knowledge of much of the surrounding country. He has traveled some, but the expanse of the empire is so large as to be practically infinite, and so his knowledge is limited. Asserting the impossibility of contact with "the northerners," he claims that "the land is too vast and would not let them reach us, they would end their course in the empty air." ${ }^{44}$ Despite this apparent spatial restriction, the influence of China's leaders is omnipresent in all corners of life. "Our leaders know us," he says, "They, absorbed in gigantic anxieties, know of us, know our petty pursuits, see us sitting together in our humble huts, and approve or disapprove the evening prayer which the father of the house recites in the midst of his family." 45 The image of Bentham's panopticon, so often invoked in Kafka criticism, seems inescapable here. The prying eye, peering into the confines of humanity's most private experiences, passing judgment that can neither be

\footnotetext{
42 Sokel 17

${ }^{43}$ KAR 77

${ }^{44} \mathrm{KCS} 241$

45 KCS 241
} 
confirmed nor denied. The "anxieties" of the leaders underscores the sense that the source of judgment is neither the austere, unquestionable deity of the Christian tradition nor the collection of high-minded equals that constituted the polis. These leaders are subject to the same worries as their subjects - only made "gigantic" - and eminently concerned with the "petty pursuits" which make up the activities of the private realm; they are Gods fashioned in man's image, but this a particular kind of socialized man who thinks primarily of daily needs, quotidian cares, and reflects these thoughts back onto the organizing principle of his own life. "Kafka depicted a society which had established itself as a substitute for God," Arendt writes, "and he described men who looked upon the laws of society as though they were divine laws - unchangeable through the will of men." ${ }^{46}$ Divinity, the unquestionability of an authority handed down from on high, requires obscurity. "The most obscure of our institutions is that of the empire itself," 47 the narrator says, and he emphasizes over and over again the extent to which the Chinese people cannot even be sure that their Emperor exists. ${ }^{48}$ The opacity of the leaders, the absolute impossibility of engagement with them in any form, precludes any form of resistance, any chance at rebellion. The diffuseness of the leadership presence makes their influence a matter of internalization, a deep-seeded infection that spreads outward exponentially like a virus. Everyone in China is susceptible to it because the belief in its validity is so crucial to their sense of national identity, the binding agent that prevents individuals from foundering in a

\footnotetext{
46 KAR 72

47 KCS 242

${ }^{48}$ Additionally, the reader remains unsure who exactly is in charge here. The high command, the Emperor, and "nature Gods" are all considered separately, and therefore must be distinct entities. This ambiguity emphasizes the extent to which the gaze of authority extends into every facet of private life, and permits nothing in terms of reciprocality.
} 
sea of uncertainty.

Arendt writes that "the phenomenon of conformism is characteristic of the last stage of this modern development," ${ }^{49}$ and we can see the ways this plays out as necessity in "The Great Wall." The conflation of the public and private, the sense in which there is no space in which the eyes of the leadership do not pry, fosters the conformity of the Chinese people. But the innate desire of humankind to bind itself to a coherent worldview is not enough in itself to ensure that fragmentation does not occur; there is always a material, private concern that overrides all others. The rise of society is, after all, not merely predicated on an abstract ideal that proceeds with or without specific kinds of organization; socialization requires reification in order to become dominant. In "The Great Wall," the building of the wall provides the concrete structure that makes tangible the rather mystical scope of the empire. In case there is any doubt as to the codependence of the empire and the wall, the narrator makes it explicit: "Far rather do I believe that the high command has existed from all eternity, and the decision to build the wall likewise." ${ }^{50}$ By giving the wall and its conceivers an eternal quality, the whole process of socialization that the wall engenders appears to progress inevitably, as a kind of dialectic. ${ }^{51}$ Moreover, the high command elevates the craft of masonry "as the most important branch of knowledge throughout the whole area of China," 52 ensuring that reification of conformity attends to the same desires as the abstract ideals which will belief in the leaders' eternal path of inevitability.

\footnotetext{
${ }^{49} \mathrm{HC} 40$

50 KCS 242

${ }^{51}$ Considered as a dialectic movement, it is interesting that the story begins with an assertion of completion; as if the dialectical synthesis had been achieved. However, as we shall see, the wall is never really "finished." They still have to build the Tower of Babel.

52 KCS 236
} 
Education, the system by which a population learns norms and values, prioritizes the wall to the exclusion of all else; including, we might assume, the critical faculties that would undermine the legitimacy of the wall and the high command. Here we have a kind of mockery of the pursuit of excellence found in the public sphere, carefully directed and promoted by anxious Gods who think only in terms of the private, and "see the body of peoples and political communities in the image of a family whose everyday affairs have to be taken care of by a gigantic, nation-wide administration of housekeeping." 53

If "The Great Wall of China" provides a compelling example of socialization at work, "The Burrow" seems to be its opposite. The burrower is fiercely individualistic, nonconformist, and asocial - the opposite of the Chinese wall-builder who goes about his task with the weight of the nation, "a current of blood no longer confined within the narrow circulation of one body, but sweetly rolling and yet ever returning throughout the endless leagues of China." 54 The burrower's structure is designed to seclude its subject from society, not to integrate it. He also wishes to mix his blood with his building - "I was glad when the blood came, for that was a proof that the walls were beginning to harden" 55- but works at every moment to assure it is only his blood that seeps into the structure. Privacy and solitude are panaceas for all that ails him. He appeals to no God-like authorities, and constantly rebels against the natural conditions given to him. In many respects he seems to be the "deviation" which social science fails to account for. But this is misleading. The burrower is, in fact, just as conditioned by the strictures of society as any Chinese laborer.

To get to how this is so, we must first examine his place in Arendt's delineations.

\footnotetext{
${ }^{53} \mathrm{HC} 28$

${ }^{54} \mathrm{KCS} 238$

55 KCS 328
} 
Everything the burrower does is intensely private. As Hermann Weigand notes, "he thinks of nothing but himself and his burrow," 56 directing all of his inquiries back towards his myopic focus on privacy, security and "self-glorification." Even the self and its creation are integrated; Heinz Politzer writes: "Literally the creation harbors the creator; moreover, it swallows him up to such an extent that he himself is denied any identification." 57 The narrator's creation is an integral part of him rather than a passive object, an extension of his psyche rather than something that psyche reflects upon. In this analysis, the burrow is not something the narrator can observe or appreciate, or rather only to the extent that the self can observe or appreciate itself; it is himself that he watches, and himself that he gloats over in his obsessive and pedantic commentary. "What do I care for danger now that I am with you," he says, addressing the burrow directly, "You belong to me, I to you, we are united, what can harm us?" 58 The burrow, then, is an extension of the burrower's body, the place where the most private processes imaginable occur; digestion, reproduction, defecation, etc. ${ }^{59}$ As such, the life of the burrower/burrow follows the same logic as the progression of the biological process. The burrow is not something the burrower merely uses to facilitate a more comfortable life or a life freed from the cares of necessity; by identifying himself with his burrow to such a great extent, the use-value of the burrow as an object becomes a tied directly to the life-process which consumes itself continuously in order to exist. Thus the burrow must remain forever in media res, lest its completion bring about an end to the process that sustains its creator, just as labor is necessary to sustain

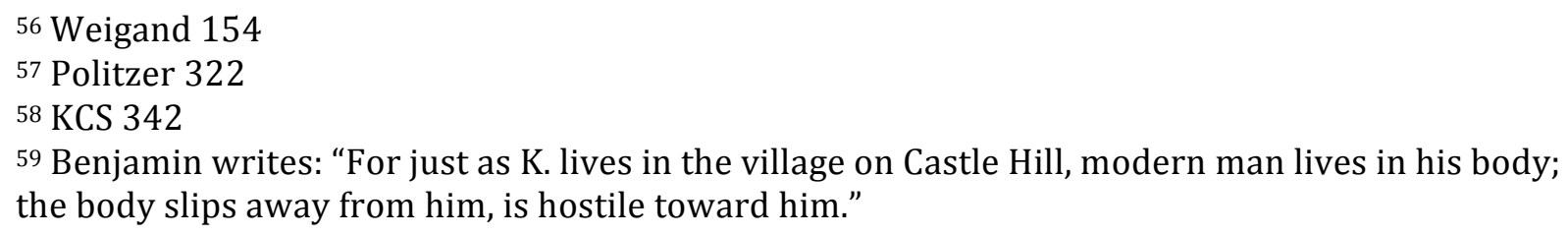


human life. As in "The Great Wall," our narrator begins his story with an assertion of this completion, and in the end the cessation of the process brings about his self-destruction through the mysterious "whistling," which severs the progression of life and plants him a present with no future. After indeterminate time spent trying to ascertain the cause of the whistling, and the commencement of "experiments" which only disfigure the burrow because they lack the dialectical force which propelled all previous efforts, ${ }^{60}$ the burrower can only hunker down in his Castle Keep, "choose a lovely piece of flayed red flesh and creep with it into one of the heaps of the earth; there I shall have silence at least, such silence, at any rate, as still can be said to exist here." 61

What relevance can this strange animal and his obsessive attraction to his home have for the human in modern conditions? For one, it shows the disintegration of the private realm in the modern world. In antiquity the private existed as a counterpart of the public, enabling the transition that was necessary for a man to shed his familial responsibilities and take on the public duties of the citizen. If we saw in "The Great Wall" how the conflation of public and private can lead to an omnipresent authority that seems unassailable, here we witness what happens when the public disappears altogether and the only recourse left for an individual is located in the private activities. This does not diminish the desire for the benefits which the public sphere afforded, however; they are merely disfigured by the absence of a proper place for expression. The disintegration of the private is not an idiosyncrasy of Kafka's strange dream-world. It is the outcome of a certain

\footnotetext{
60 We will discuss this further in the next section, but a short quote can't hurt: “...this time everything seems difficult. I am too distracted, every now and then, in the middle of my work, I press my ear to the wall and listen, and without taking notice let the soil that I have just lifted trickle back into the passage again." KCS 350

${ }^{61} \mathrm{KCS} 358$
} 
set of conditions, ways of thinking and acting that only emerge in the socialized world of modernity.

For Arendt only an animal can live a truly private life, "deprived of the reality that comes from being seen and heard by others... deprived of an 'objective' relationship with them that comes from being related to and separated from them through the intermediary of a common world of things... deprived of the possibility of achieving something more permanent than life itself." 62 For our burrower, who has no apparent interest in interacting with anyone or engaging in any kind of common space, the self-glorification which he so assiduously craves finds its object in the burrow, with himself as the observer reveling in the structure which he identifies so deeply with - ".. it is as if I were not so much looking at my house as at myself sleeping, and had the joy of being in a profound slumber and simultaneously of keeping vigilant guard over myself." 63 The role of the other in the public sphere is excluded, and the necessary condition of humanity - being amongst others - is relocated to the space of fantasy, the dream of doing away with others and yet still achieving the "joy" of observing the self and its self-aggrandizing objects. The way Kafka mixes the natural cares of the animal - food, security, safety - and the "higher" aims of the human creates a strange dysfunction, a cancelling-out of the public and private that leads to nothing but endless anxiety and fear (as well as small moments of fleeting joy).

Arendt notes the "modern discovery of intimacy seems a flight from the whole outer world into the inner subjectivity of the individual, which formerly had been sheltered and

\footnotetext{
62 HC 58

${ }^{63} \mathrm{KCS} 334$
} 
protected by the private realm." 64 "Thus modern property," she writes later, "lost its worldly character and was located in the person himself, that is, in what an individual could lose only along with his life." 65 The burrower makes clear that losing his property is analogous to, if not worse than, losing his life. His ceaseless watching from above, his temporary wish to flee the spot forever rather than expose it to his enemies, indeed all of his activities once he has decamped from the interior illustrate his very bodily and biological connection to the burrow. It is as if he considers himself as an appendage of the burrow, one that must be amputated if necessary in order to maintain the health of the larger body. To consider one's home in this way is only possible when the private sphere is the last recourse and all possibility of movement is cut off; in short, when the public sphere has disappeared and the private becomes the totality of the world.

This does not rule out the presence of others; it only restricts their particular constitution from the subjective perspective. There are some "others" in "The Burrow," and they characteristically take the outward form of predators and bandits. During his short lived hunting excursion to the topside, the burrower observes the activity going on near the entrance:

Here enemies are numerous and their allies and accomplices still more numerous, but they fight one another, and while thus employed rush past my burrow without noticing it. In all my time I have never seen anyone investigating the actual door of my house, which is fortunate both for me and

\footnotetext{
${ }^{64} \mathrm{HC} 69$

${ }^{65} \mathrm{HC}$ 70. In contemporary terms we might think of the belligerent home-owner standing in front his house with a rifle screaming "Over my dead body!" Rather death than loss of property.
} 
for him, for I would certainly have launched myself at his throat, forgetting everything else in my anxiety for the burrow. ${ }^{66}$

These "enemies" show no interest in the burrow, not here nor anywhere else over the course of the narrative. Their enmity is entirely constructed from imagination. ${ }^{67}$ The burrower relates an incident that occurred in his youth, when he was "nothing more than a humble apprentice," 68 in which he hears a noise from outside the burrow that resembles his own laboring sounds. In this early stage of his life, the other is merely a source of curiosity; the potential for public engagement has not yet closed entirely. "I probably would not have been displeased to see the burrower suddenly rising from the ground..." ${ }^{69}$ It is clear that as the building of the burrow progresses, and it gets closer to the ideal burrow that its creator has in his mind, the concept of privacy grow in importance until it becomes all-consuming, as if the burrower becomes more aware of his own body and thus more aware of its mortal vulnerability. Instead of overcoming this existential anxiety by transcending his "life=span into past and future," 70 i.e. by entering the commons, he follows the historical progression of socialization and turns inward.

Of course we must remember that he is an animal, not a human, and subject to different kinds of interrelational criteria than, say, the citizens of China. ${ }^{71}$ But part of the mystique of Kafka's animal stories is that they seem familiar, constantly compelling the

\footnotetext{
66 KCS 334

${ }^{67}$ Near the end of the story, after he has practically given up hope for his burrow and himself, he betrays as much: "Outside there nobody troubles about my burrow, everybody has their own affairs, which have no connection with me." KCS 352

68 KCS 355

${ }^{69} \mathrm{KCS} 356$

${ }^{70} \mathrm{HC} 55$

${ }^{71}$ As Benjamin notes, this is often easy to forget in Kafka: "It is possible to read Kafka's animal stories for quite a while without realizing that they are not about human beings at all." Benjamin 122
} 
reaction "'that's the way it is,' and with it the question, "'where have I seen that before?"' 72 despite their non-human subjects. Arendt describes how the disappearance of the private life ("The Great Wall of China") or the private life itself ("The Burrow") has forced the Kafka character "into abandoning all human traits and into fulfilling his function as though he were inhuman." 73 For both Arendt and Kafka this is a loss, something the former makes explicit and the latter alludes to through oblique desires. In "The Great Wall" the Chinese express the desire to touch the emperor, to feel his presence in their lives in a tangible way: ...there is also involved a certain feebleness of faith and imaginative power on the part of the people, that prevents them from raising the empire out of its stagnation in Peking and clasping it in all its palatable living reality to their own breasts, which yet desire nothing better than but once to feel that touch and then to die. ${ }^{74}$

This weakness is one of the "greatest unifying influences" on the Chinese people, the "very ground on which we live." The sense is that to see the Empire as a human institution would destroy the very foundations of its organization. The wall reifies the empire by closing it in and uniting the people in a common labor, but its immensity, the infinite scope of it reaching beyond all human understanding, is a necessary condition for the population. The establishment of a public sphere is precluded by this immensity, by the privacy of their desire to feel the body of the leader, by the conformism engendered by their unwavering faith in this incorporeal idea. The narrator's emphasis on "the ground" reinforces the notion that the very constitution of reality relies on the empire for coherence, depriving the

\footnotetext{
72 Adorno 246

${ }^{73}$ KAR 76

${ }^{74}$ KCS 247
} 
Chinese of their own ground, their own private space. ${ }^{75}$ They have lost their basic humanity by becoming dependent and forsaking their agency to act in the world.

The most important point in this discussion of public and private, from the Arendtian point of view, is the requirement that both spheres co-exist simultaneously for either to have any real distinction. The rise of the social is the blurring of the lines that separate them, their conflation under conditions that destroy the sanctity of each and bring them under a single, infinitely controllable realm. "The Burrow" and "The Great Wall" describe this process in two very different ways and from two very different perspectives, but the outcome is essentially the same: the social subject cannot act in any real sense. The Chinese people are ruled by a disembodied authority that cannot be known. The burrower is similarly ruled by an unknowable authority, but it is a force located within himself, predicated by animal instinctiveness mixed with a human penchant for self-glorification. The point is that both act in accordance with a certain inevitability that closes off the prospect for something new. "...I know that my term is measured, that I do not have to hunt here forever, and that, whenever I am weary of this life and wish to leave it, Someone, whose invitation I shall not be able to withstand, will, so to speak, summon me to him." 76

\section{III.) Labor and Work}

In The Human Condition Arendt moves from considering the spaces of human activity and their transformation under the social to the activities themselves. The first two

\footnotetext{
75 It is also shows, once more, how the private has exploded into the realm of the public. There is no "my" ground, there is only "our" ground, no individuals, only "the people."

76 KCS 334
} 
categories of the vita activa are work and labor. ${ }^{77}$ She admits that making a distinction between these two concepts is "unusual," as not even Marx saw fit to draw this line. Nevertheless, Arendt claims that the distinction is crucial to understanding human activity, and cites the fact that every European language contains two separate terms for these activities, "and retains them in the face of their persistent synonymous usage." 78

As she provides short definitions for both concepts at the beginning of the book, I will quote her at length:

Labor is the activity which corresponds to the biological process of the human body, whose spontaneous growth, metabolism, and eventual decay are bound to the vital necessities produced and into the life process by labor. The human condition of labor is life itself.

Work is the activity which corresponds to the unnaturalness of human existence, which is not imbedded in, and whose mortality is not compensated by, the species' ever-recurring life cycle. Work provides an "artificial” world of things, distinctly different from all natural surroundings. Within its borders each individual life is housed, while this world itself is meant to outlast and transcend them all. The human condition of work is worldliness. 79

Labor is repetitive and never-ending, concerned solely with biological processes that humans share with animals. In Arendt's view, a beaver constructing a dam or a

\footnotetext{
77 I will not discuss the third category, action, primarily because the conditions for Arendtian action are never presented in Kafka. Action is emancipatory, constructive; Kafka's characters are always mired in a present they wish to "obliterate."

${ }^{78} \mathrm{HC}$, see footnote 3 on pp. 80

${ }^{79} \mathrm{HC} 7$
} 
squirrel gathering nuts for the winter are both activities that fall under the category of labor, as befits the operative term denoting the subject of labor, the animal laborans. Slaves are also animals laborans, excluded from the political realm which is the only arena in which citizenship and meaningful speech are possible, and hence the only one in which someone can be truly human. ${ }^{80}$ It is the presence of others, the single being's place in plural mankind that defines humanity, and "the activity of labor does not need the presence of others." 81 The products of labor are immediately consumed and leave no trace on the world, and thereby have no effect on humanity as a whole.

This is not to say that labor is necessarily a solitary activity. Marx, after all, spent his entire life trying to establish labor as the essential condition of humankind, the thread that ties us all together. ${ }^{82}$ Arendt acknowledges that labor is absolutely necessary; it is the elevation of labor into a privileged position in the hierarchy of activity ${ }^{83}$, its entrance into the hallowed sphere of the public, that she (in opposition to Marx) seems to decry. "The rather uncomfortable truth of the matter is that the triumph the modern world has achieved over necessity is due to the emancipation of labor, that is, to the fact that the animal laborans was permitted to occupy the public realm." This "uncomfortable" triumph has effectively eliminated the public sphere as a space of action, degrading it from the collection of equals engaged in political activity - like that of the Greeks - into a kind of

\footnotetext{
80 The reference to slaves is Aristotle's, cited (but certainly not endorsed) by Arendt on HC 84 81 HC 22

82 The fact that Marx's ideal society ends up abolishing labor is a contradiction that Arendt explores throughout this chapter. Ex. "...the revolution, according to Marx, has not the task of emancipating the laboring classes but of emancipating man from labor; only when labor is abolished can the 'realm of freedom' supplant the 'realm of necessity."' HC 104

${ }^{83}$ see HC 17 for the reversal of "hierarchical order" of the vita activa
} 
bedroom with no walls, with "private activities displayed in the open." 84 The ascension of labor has enabled "socialized mankind," the "reversal of all traditions" which characterizes modernity. ${ }^{85}$ While all humans and animals may require labor power to enable life and the survival of the species, this requirement is only the barest minimum for life to exist.

Humanity needs more than this to distinguish itself from animals and to create a history for itself that endures beyond the single life.

Part of this need is fulfilled by work, which provides durability by means of fabrication: “homo faber who makes and literally 'works upon' as distinguished from the animal laborans which labors and 'mixes with."' 86 This durability is not everlasting. We use the products that work creates, and this use eventually causes decay, a return to "the overall natural process from which they were drawn and against which they were created." But by adding an element of temporal longevity to the human artifice, mankind can achieve an approximation of the Platonic Idea, the fantastic model towards which an object's creator strives. While the product of work is as subject to the inevitable processes of decay as the product of labor, the model itself survives and ensures permanence. A chair may crumble back into bits of wood, but chairs in general remain viable, regardless of the biological existence of the builder. This enables a stable context that delineates man from nature, providing a "man-made world of things... a home for mortal men, whose stability will endure and outlast the ever-changing moment of their lives and actions." 87 This is what Arendt means by "worldliness."

\footnotetext{
${ }^{84}$ HC 133

85 HC 85

${ }^{86} \mathrm{HC} 136$

87 HC 173
} 
The products of homo faber are use products, designed and crafted with a specific end in mind. The end justifies the means which are used to achieve it. For example, the chair justifies carving the wood and the wood justifies killing the tree. 88 "During the work process, everything is judged in terms of suitability and usefulness for the desired end, and for nothing else." As Arendt notes, the means-ends relationship creates a ceaseless chain, one where each product must lead to another, more refined product. Thus there is actually no ultimate end and hence no way to justify the means in the first place.

For an end, once it is attained, ceases to be an end and loses its capacity to guide and justify the choice of means, to organize and produce them. It has now become an object among objects, that is, it has been added to the huge arsenal of the given from which homo faber selects freely his means to pursue his ends. ${ }^{89}$

In other words, once the work process stops, the fruits of the process no longer bear the finality of an end. They are absorbed back into the process itself and become the means to something else, some further end. The chair, for example, must provide a more comfortable manner of sitting, or be sold for profit after it is finished in order to fit into the category "chair" and not be just an arbitrarily nailed-together collection of lumber. The only way out of the endless chain is to invoke the Kantian "means-in-itself," which amounts to tautology when we are talking about utility. ${ }^{90}$

\footnotetext{
88 This is Arendt's example, HC 153

${ }^{89} \mathrm{HC} 154$

${ }^{90}$ Nor does the way out consist of making man, rather than objects, an "end-in-himself." For this is to "degrade nature and the world into mere means, robbing both of their independent dignity." HC 156. Humankind relies on its worldliness, its presence among created things, to define its own humanity.
} 
Art on the other hand, which has a strained relationship to both work and labor, is created without any intention of usefulness, making it more durable than the products of homo faber. The creation of art partakes of work through reification - like use products - by hands which transform the idea into a tangible objects: poems, paintings, sculptures, etc. Art springs from feeling, which is transformed into thought, which can then become things and enter the world. As opposed to "cognition" and "science," thought "has neither an end nor an aim outside itself, and it does not even produce results." ${ }^{91}$ The physicist, whose mental process is cognition, searches for a solution to a particular problem, and once that solution is found the problem is dissolved. The means and ends are quite clear and distinct. For the artist, whose particular problems are as insoluble as the "question for the meaning of life," 92 the process is not so simple.

Kafka reveals the strangeness of his conception of means and ends, labor and work, in a diary entry, in which he describes a wish to "attain a view of life (and - this was necessarily bound up with it - to convince others of it in writing), in which life, while still retaining its natural full-bodied rise and fall, would simultaneously be recognized no less clearly as a nothing, a dream, a dim hovering." ${ }^{93}$ He explicates this wish by way of analogy: ....as if one were to hammer together a table with painful and methodical technical efficiency, and simultaneously do nothing at all, and not in such a way that people could say: "Hammering a table together is nothing to him," but rather: "Hammering a table together is really hammering a table together to him, but at the same time it is nothing," whereby certainly the hammering

\footnotetext{
${ }^{91} \mathrm{HC} 170$

92 HC 171

93 Wagenbach 45
} 
would have become still bolder, still surer, still more real and, if you will, still more senseless. ${ }^{94}$

On the one hand we have a textbook example of the work process, "painful and methodical," moving towards a useful end, that is a finished table. Yet this process is also a "nothing." What could it possibly mean to build a table and also to do nothing? Common sense implies the end as built into the formulation as table-building, leading to a very clear and established purpose. By emphasizing the co-existence of this normal way of thinking "Hammering a table together is really hammering a table together" - and the ongoing process of nothingness, the "senselessness" of the end is made clear. The table is real, yet it means nothing, because it is not an end-in-itself and reveals itself in utilitarian terms to be just another endless process. In effect, Kafka wishes to have his cake and eat it too. And further, by using this analogy to illustrate a wish for a particular "view of life," with its "natural full-bodied rise and fall," the convergence of the work process and the life process manifests the patent absurdity of ascribing a meaning to life, no less than to ascribe a meaning to work. It is this lack of meaning, this lack of sense, that makes the entire process real and worthwhile, or at least sustainable. One could say that, for Kafka, this is the entire raison d'être of the work of art. The work of art is as much a labor - in that it has no meaning besides the sustenance of life itself and is consumed by the artist as part of this "full-bodied" life process - as a work, in that it aims toward a reified object with a use but no sense. Kafka's way out of the means and ends chain is to deny that the end exists at all,

\footnotetext{
94 Wagenbach 45. For differing views of this passage, see Wagenbach p. 44-46 and Corngold 130132 (Lambent Traces). Also worth considering is this passage from "The Knock at the Manor Gate," quoted by Benjamin: "I cannot tell now whether she knocked on the gate out of mischief or out of absence of mind, or merely threatened it with her fist and did not knock at all." KCS 418. There are countless more examples of the contradiction in many other stories.
} 
at least as something attainable. The object of work qua art is a "dream, a dim hovering." This dream points towards something impossible: "It is entirely conceivable that life's splendor forever lies in wait about each of us in all its fullness, but veiled from view, deep down, invisible, far off." 95

Kafka makes sure to note, immediately following the expression of this desire, that "he could not wish in this fashion, for his wish was not a wish, but only a vindication of nothingness..." 96 The world of Kafka's stories is not this fantasy of table-building and doing-nothing co-existing; while I must confess I'm not sure what that kind of world would look like, we can be certain that the Kafka character inhabits a world in which every process results in a something, even if that something is unfathomable. As we have established, these characters live in a socialized world, and it is only in this kind of world that Kafka can express the inevitable failure of this wish. In the modern world there is no way out of the means-ends chain that socialization entails.

For the ancients, in Arendt's analysis, the products of work would have only ancillary connection to the activities of animal laborans, because the former exists in a world, whereas the latter has no world besides the one located in the individual body. While it is true that the homo faber has to eat (and thus labor), this necessity can be satisfied either by leaving the realm of work and temporarily becoming an animal laborans, or by having slaves; the important thing is that the homo faber's products are not immediately consumed. "The man-made world of things, the human artifice erected by homo faber, becomes a home for mortal men, whose stability will endure and outlast the

95 Diaries 393

96 Wagenbach 46 
ever-changing movement of their lives and actions..." 97 The onset of socialization, with its unequivocal emphasis on use-value and its conflation of public and private, brings with it the subsumption of work into labor and the alienation of humankind from itself and the products of its work. Everything is evaluated according to its use (including labor and thus human life), and everything which achieves its end is consumed by something else.

In an essay on "The Metamorphosis," Walter Sokel defines "self-alienation" as "the individual's estrangement from his humanity or 'human species being,' i.e., from the individual's membership in the human species. The individual is estranged from himself insofar as he is alienated from his essential nature as a human being." 98 In Arendtian terms, Sokel is describing "loss of the world." In order to overcome self-alienation, in the Marxist view, work must not be "dictated by external needs or the commands of others," but "chosen, partially at least, for its intrinsic pleasure." Only in this way can work be an end-in-itself and not a means for something else, and thus man can realize his humanity through his own free will. It is characteristic of modernity that the possibility for this kind of free labor is excluded, a fact Sokel sees exemplified in Gregor Samsa's activities - always "externalized," always belonging to someone else. ${ }^{99}$

We can also see the manifestation of self-alienation in "The Great Wall of China." The primary cause of this is the wall's "piecemeal construction"; the importance of this method in the building process is so great the narrator calls it "one of the crucial problems in the whole building of the wall... If I am to convey and make understandable the ideas and

\footnotetext{
97 HC 173

98 Sokel 217

99 "For not only is his labor alien to his true desires, but its sole purpose, its fruit - the salary or commission that it affords him - does not even belong to him. Gregor's toil does not serve its own existence." Sokel 218
} 
feelings of that time I cannot go deeply enough into this very question." 100 The narrator begins his report by noting that the piecemeal construction in many ways defeats the purpose of the wall itself. The goal is ostensibly for it to "be a protection against the peoples of the north," which raises the question "how can a wall protect if it is not a continuous structure?" 101 As the narrator notes, the enemies of China have a better view of the construction than the builders themselves, and tear down the sections faster than they can go up. The answer to this conundrum, of course, is that the wall is not designed for protection at all. Its real purpose is the mobilization of "two great armies of labor," which are divided into smaller groups of twenty and transferred to all corners of the empire whenever they've finished their five-hundred yard sections. Furthermore, the "more purely manual tasks" are undertaken by "ignorant day laborers," over which a well-trained supervisor "capable of entering into and feeling with all his heart what was involved" 102 presides, creating another echelon in the labor hierarchy and increasing the distance between worker and finished product. In short, it severs the Chinese citizen from his human connection to home and work. ${ }^{103}$ This connection is replaced by love for the wall, for the nation, for the emperor, and a general sense of unity that, in effect, turns the plurality into a population. ${ }^{104}$

\footnotetext{
100 KCS 238

101 KCS 235

102 ibid

${ }^{103} \mathrm{~J}$. Mitchell Morse has written an interesting article on the relationship between Kafka's wall and the real Great Wall of China, which is tenuous at best: "...Kafka's myth has nothing to do with the grim facts recounted by Zhewen and Luo."

104 "Accordingly, while they were still exalted by the jubilant celebrations marking the completion of the thousand yards of wall, they were sent far, far away, saw on their journey finished sections of the wall rising here and there, came past the quarters of the high command and were presented with badges of honor, heard the rejoicings of new armies of labor streaming past..." etc, etc.
} 
Arendt articulates the modern division of labor perfectly:

Since none of the activities into which the process is divided has an end in itself, their "natural" end is exactly the same as in the case of "undivided" labor; either the simple reproduction of the means of subsistence, that is the capacity for consumption of the laborer, or the exhaustion of human labor power.

What is lost is the connection the homo faber has to the object he creates. The "ignorant day laborer" is extremely disconnected from the fruits of his activity, content to offer his services for "good money" and thus investing no more in the wall than the means for his own subsistence. For Kafka's narrator this figure is of little interest, almost a given under the conditions in which China exists - despite (or because of) the fact that this group makes up the majority of the Chinese population. The real conundrum is the well-educated mason/supervisor, indoctrinated from a young age by a school system focused entirely on the wall, who feels himself to be "a part of the wall," 105 but will never see the product of his labor in its entirety. For this category of worker something more than the mere subsistence of the life process is required. "Masons of that kind, of course, had not only a desire to perform their work in the most thorough manner, but were also impatient to see the wall finished in its complete perfection." 106 This impossible desire sustains the mason the way a paycheck sustains the day laborer. It gives meaning to the supervisor's existence.

Yet both categories of work face a similar problem: the end of the labor process, the production of the wall or the money that results from it, is disconnected from the labor 
itself, much like the modern factory worker who handles one task that eventually leads to something useful only after hundreds of other mundane tasks come together as if by magic. In "The Great Wall" there is almost infinite faith in the planning, the foresight, the thought that has gone into the building from at least "fifty years before the first stone was laid" 107 and possibly from "all eternity." This faith is absolutely necessary to the stability of the structure, to maintain the "ground on which we stand." In a sense Kafka takes the logic of the assembly line to its farthest conclusion, imagining a process wherein neither the laborer nor the supervisor ever sees the finished product yet continues to work as if it must exist, for to acknowledge the futility or emptiness of the task would be to give up on life itself. In this way the means become the end, and work becomes labor.

Unlike Marx, Arendt finds no solace in work or labor as an end-in-itself. ${ }^{108}$ This is the genesis of her entire distinction. The essence of humanity in its uniqueness is its ability to construct a history and to continuously begin something new; labor, even "free" labor, can only recycle the life process (which means nothing in and of itself). The wall does achieve the durability that constitutes the product of work - "the wall was to be a protection for centuries" 109 - but the vastness of the space it (supposedly) encloses makes it useless as an object. If we insist on ascribing a use to the wall, from above as it were, it is to provide the material conditions which promote conformism and reifies the diffuse power of the high command; this, however, presupposes that the high command actually

107 KCS 237

108 "Within a completely "socialized mankind," whose sole purpose would be the entertaining of the life process - and this is the unfortunately quite unutopian ideal that guides Marx's theories - the distinction between labor and work would have completely disappeared; all work would have become labor because all things would be understood, not in their worldly, objective quality, but as results of living labor power and functions of the life process." HC 89

109 KCS 236 
exists, a fact we cannot be too sure of: "where it was and who sat there no one whom I have asked knew then or knows now." 110 Nevertheless, something called "the high command" animates the desires of the entire Chinese people, to the extent that without it "neither our book learning nor our human understanding would have sufficed for the humble task which we performed in the great whole." 111

In "The Burrow," which has often been read as an allegory of Kafka's own struggles as an artist, 112 the activities of the burrower are apparently motivated more by internal processes than the external force which animates the Chinese worker. If we accept the allegorical-biographical reading for a moment and recall Kafka's table-building process, we can see how the distinctions between labor and work get mixed up when the artistic object is both useful and purely aesthetic, a "nothing." Like the Great Wall, the burrow's ostensible use is protection and security, but it also facilitates a process that has no end, the eternal recurrence of a life process that finds meaning in "self-glorification." The burrower wishes with all his heart to detach himself from any use function the burrow might have:

One of these favorite plans of mine was to isolate the Castle Keep from its surroundings, that is to say, to restrict the thickness of its walls to about my own height, and leave a free space of about the same width all around the Castle Keep, except for a narrow foundation, which unfortunately would be left to bear up the whole. ${ }^{113}$

In this wish, the burrower lives in a space directly outside the Castle Keep but never enters

$110 \operatorname{KCS} 239$

111 KCS 239

112 For example, see Henel, Boulby, and Maché

113 KCS 346 
it; all of the labor that has gone into it, all of its use as a storage place for food, is sacrificed for the joy of being able to "stand guard over it, and in that way to be so completely compensated for renouncing the actual sight of it that, if one had to choose between staying all one's life in the Castle Keep or in the free space outside it, one would choose the latter..." In this way the Castle Keep could become both a use-object and a nothing, its usefulness forever deferred and merely reveled in as a sort of abstract idea. ${ }^{114}$ Heinrich Henel notes that "to live all one's life in a hollow around a hollow is the non plus ultra of the animal's dreams," 115 a situation in which he can contemplate the object's perfection without using it up and exposing it to danger. This is always an imminent threat due to the burrower's uncontrollable animal instincts. Giving into his ravenous urges make for "happy but dangerous hours," 116 a time when he is strictly an animal laborans and risks the worldliness of his creations as stable objects. "The Burrow" is full of these kinds of internal antagonisms, the desire to make lasting objects and the desire to consume them, the desire to observe and the desire to devour. The burrower knows that by using his burrow as a home and storage facility he is sacrificing its durability as object and its perfectibility as artwork.

This is a problem that does not arise when there are clearly demarcated spaces for activity. The activities of animal laborans go on in the privacy of the home, while the work of homo faber creates a durable world in which the public sphere is made possible, and necessarily moves the individual out of the home. As Arendt notes, "without a world

114 KCS 346

115 Henel 233

116 KCS 331 
between men and nature, there is eternal movement, but no objectivity." 117 Only by the creation of this world can men relate to one another, and move out of the endless circle of nature through the transformation of nature into lasting objects. "The Burrow" seems to be a perfect description of this transformation, but the lack of any kind of public sphere denies the burrower a place for giving expression to each kind of desire distinctly. The circular, consumptive process that goes on in the home is conflated with the durable, lasting process of the world, a conflation that ultimately causes the burrower to self-destruct in a psychotic fit of anxiety. After the introduction of the "whistling" noise that drives him to despair, the burrower tries to eat, but it is unsatisfying: "...I spit out my food, and would like to trample it underfoot, and go back to my task, not caring which I take up." 118 The labor process of gathering and eating food has become mixed up with a work process that originally aimed to solidify the burrow's defensive capabilities, but now has no real end besides the reflexive exhumation of excess labor power. The burrower cannot enjoy his food because his higher needs - security, silence, beauty - no longer have a space for expression.

Again we might draw an analogy to the modern factory worker, or even broaden it to include every kind of "wage-slave" trapped in a circular process whereby the fruit of their labor (money) is used to purchase food to maintain the life process so that the worker can go back to his job the next morning. Every activity is predicated on preventing the destruction of the life process, and on that alone. The burrower did not always act under these conditions; it is only when the whistling begins that he works "just as if the overseer

117 HC 137. We will discuss the epistemological implications of "objectivity" in the next section. 118 KCS 351 
had appeared and I made a pretense of working for his benefit." 119 Previously his labor had ostensibly been "free," in the Marxist sense that he undertook it of his own accord and maintained his connection to the end product throughout the process. Yet the story reminds us again and again that this kind of labor is not really free, it is as externally dictated as the activities of Chinese wall-builders. He is always subject to a hostile natural world that he himself has imagined, and thus subject to his own overwhelming fear. His activities are reactions against this self-made threat and often impede his happiness; happiness is a danger that lowers his guard and opens him up to attack.

One might say that this is still freedom; after all, it is only the burrower's raging delusions that prevent him from being a happy and well-adjusted individual, and he is perfectly free to shed these delusions whenever he gathers the willpower to do so. There is also the sense - and this is supported by the burrower himself - that if he had just worked harder all possible contingencies could have been accounted for and complete security achieved. ${ }^{120}$ In short, he could give up the dream of perfect security and appreciate his burrow for the grandiose self-glorifying edifice that it is, or he could abandon the dream of ever enjoying his burrow, and work on it nonstop for his entire life. It should be obvious by now that neither possibility is open to the burrower. His nature as homo faber demands a use-value for his work; conversely, his concurrent nature as animal laborans requires a continuous consumption of everything he produces. In the modern, socialized world the specific spaces for these activities have been subsumed by each other, and we are left with the confusion of means and ends which attends the mixing of work and labor: "instead of

119 KCS 351

120 "I have rested far too often from my labors all my life" KCS 356 
thinking only of my own defense - and how perfunctorily and vainly I have done even that - I should have thought of the defense of the burrow." 121

This attention to the object - apparently for the benefit of the subject - is the thread that ties "The Burrow" and "The Great Wall of China" together. And in both cases, the power that these objects assert over those who create them is paradigmatic of the modern age. It is the power of conformism and socialization, explored in the previous section, and the power of a particular kind of activity which blends work and labor into something that alienates the worker from his product and imbues the homo faber with the circular, consumptive concerns of the animal laborans, an activity which perverts the "worldliness" necessary for human relations into one more utilitarian use-value. As Arendt says, “...the tragedy is that in the moment homo faber seems to have found fulfillment in terms of his own activity, he begins to degrade the world of things, the end and end product of his own mind and hands." 122 The process, then, the means by which to achieve an end, must become the end itself for the whole structure to function. Whether or not it has any meaning is beside the point. In the next section we will explore how this continuous process lends itself to the concept of historical necessity, and turns humans into passive subjects in an inexorable process.

\section{IV.) The Archimedean Point}

Arendt begins her last chapter, "The Vita Activa and the Modern Age," with an epigram from Kafka:

121 KCS 355

122 HC 155 
He found the Archimedean point, but he used it against himself; it seems he was permitted to find it only under this condition. ${ }^{123}$

Named after ancient Greek mathematician Archimedes, the Archimedean point is a particular vantage, located a sufficient distance from an object to allow for a total view of the object and its surroundings; theoretically, this perspective alone allows the observer to see the object without bias or interference, with complete rationality. For Arendt, the discovery of the Archimedean point was facilitated by Galileo's invention of the telescope, an event which is unsurpassed in its importance to modernity. "What Galileo did and what nobody had done before was to use the telescope in such a way that the secrets of the universe were delivered to human cognition 'with the certainty of sense-perception..."' 124 While the ideas which the telescope proved had been around for hundreds, if not thousands of years, it was their observation and measurement that proved instrumental in the end. Humanity's newfound capability to see its world objectively displaced mankind from his natural home and moved him out into the universe, a situation Arendt terms "earth alienation." But more important for our consideration is "world alienation," the "sudden, inexplicable eclipse of transcendence" 125 that simultaneously occurs in th modern age. The result of this process is that men are "not thrown back upon the world but upon themselves." ${ }^{126}$ In non-Heidegarrian language, this means that humanity reduces itself to the Cartesian cogito, denying the "real" existence of the common world and replacing it with individualistic self-care. The Archimedean point is drawn inward even as the scope of

\footnotetext{
${ }^{123} \mathrm{HC} 248$

${ }^{124} \mathrm{HC} 260$

$125 \mathrm{HC} 253$

126 HC 254
} 
human vision exponentially expands its range. Weber, as well as Marx, cite world alienation as the predominant condition of capitalism, "the hallmark of the modern age": “... an enormous, strictly mundane activity is possible without any care for or enjoyment of the world whatever, an activity whose deepest motivation, on the contrary, is worry and care about the self." 127 As we've discussed above, it this paradoxical convergence of the inward and outward that makes socialization possible. Humanity, turning towards itself while the instruments it has created continue to expand the possibilities of vision, sees itself as a mere microcosm in an enormous universe, ultimately subject to the same laws which control the motion of the stars. Under the tenets of "Cartesian doubt" the only truth that can be claimed objectively is the truth of the self, namely that it exists; everything else is fleeting, transient, perhaps illusory, certainly lacking the permanence of a stable human world.

Kafka's aphorism wonderfully shows the profound ambivalence with which he viewed modernity's progress. The idea of an uncontrollable force outside human influence - he was "permitted" to find the Archimedean point, by what or whom we do not know and the self-destructive motives of modern man are always present in Kafka's stories, from Joseph K.'s unbelievably passive execution for a crime he is still unaware of, to the mouse in "A Little Fable" who keeps running through narrowing corridors and, at the end, is faced with a trap to the front and a hungry cat to the rear. This ambivalence is further exemplified by two more brief parables. The first is called "The Tower of Babel"; the latter, "The Pit of Babel":

${ }^{127}$ HC 254. Weber calls this condition "innerwordly asceticism," and explores its impact on the rise of capitalism in The Protestant Ethic and The Spirit of Capitalism. 
1.) If it had been possible to build the Tower of Babel without ascending it, the work would have been permitted.

2.) What are you building? - I want to dig a subterranean passage. Some progress must be made. My station up there is much too high.

We are digging the pit of Babel. ${ }^{128}$

These two parables offer a remarkable entrance into our two stories. They could almost be conceptualized as précis: “...the Great Wall alone would provide for the first time in the history of mankind a secure foundation for a new Tower of Babel," 129 the narrator says, while the second parable might be a dialogue between the burrower and some imagined interlocutor. The Tower of Babel, then, provides a kind of structural bond between the two building stories, linking them to a concept of modernity that is presaged by an ancient tradition, swept up, as it were, by the Benjaminian "angel of history" who "turns his face to the past." This concept, quoted by Arendt from Benjamin's "Theses on the Philosophy of History," is worth citing in full:

Where we see a chain of events, he sees a single catastrophe which unremittingly piles ruins on ruins and hurls them at his feet. He wishes he could stay - to awaken the dead and to join together the fragments. But a wind blows from Paradise, gets caught in his wings and is so strong that the angel cannot close them. This wind drives him irresistibly into the future to which he turns his back, while the pile of ruins before him towers to the

128 Kafka, Parables and Pardoxes 35

129 KCS 239 
skies. What we call progress is this wind. 130

This, as Arendt notes, is the most exact expression of Kafka's view of progress one could reasonably hope for. We can see this readily in "The Great Wall of China." The structure, designed to foster a national organization which is undoubtedly an advance from the barbarian tribes of the north, must recall an old Biblical legend to give itself meaning, to cast an Archimedean point into the future from which the Chinese may achieve total harmony like Gods. In the meantime (and it is always the meantime in Kafka), we have the fractured bits of wall, so absurdly useless both as a protection and as a foundation. The narrator knows this: "How could the wall, which did not form even a circle, but only a sort of quarter- or half-circle, provide the foundation for a tower? That could obviously be meant only in a spiritual sense." ${ }^{131}$ So why build the wall, he asks, and unwittingly answers himself: “...for mobilizing the people’s energies for the stupendous new work?" The wall serves to bind the people to an abstract ideal that is forever receding, utilizing their activities (work and labor) to force conformity and allegiance to an obscure authority. The construction process is not possible without some sense of the Archimedean point, for only once a plurality can be considered as a population - from above - can they willingly forego their natural attachment to home and hearth, to the familiar things which constitute their world. The theory of the wall as foundation for the Tower of Babel - one of many "wild ideas in people's heads at that time" - is necessary to give some sense to the intentionally futile aims of security. Without knowing the origins of the commands, emitted at some point from the obscure high command, a transcendental unity is required, for "human 
nature, essentially changeable, unstable as the dust, can endure no restraint; if it binds itself it soon begins to tear madly at its bonds, until it rends everything asunder, the wall, the bonds, and its very self." ${ }^{132}$ The Chinese people are still very much in thrall to this transcendental power, but whereas the omnipotence of a traditional God provided man with a secure foundation to base his existence on, this new power is uncertain and ambiguous, leaving the citizen with naught but a useless wall and a firm desire to once touch the emperor and then to die. Thus the process must be continuous, always progressing so as to hold the unstable bonds of human nature together.

The burrower is swept up by a similar process, but instead of building upwards towards heaven, he digs into the ground and turns his back on the rest of the world, directing all his concerns back in on the self. "Some progress must be made," the parable reads, but progress towards what? In which direction? Rather than a process which leads towards unification and conformity, the burrower wishes to enclose himself from the world, to cement the care of the self as the only possible concern. It is as if he wishes to destroy the world so that only the Cartesian cogito is permitted to exist. As we've discussed, the burrower's nature as social being makes this impossible; the process is doomed to failure by his constant need for affirmation and glorification, to the extent that he spends much of his time imagining enemies or friends who quickly become enemies. "The social origin of the individual ultimately reveals itself as the power to annihilate him." 133 The innocuous fellow burrower, encountered long before in useful curiosity, has been transformed into a destroyer: "...the burrower has changed his intention anew, he has

132 KCS 239

133 Adorno 253 
turned back, he is returning from his journey, thinking he has given me ample time in the interval to prepare for his reception." 134 The whistling is not a coincidental development, it is the return of a repressed memory, a specter of the past reasserting itself in its full destructive power. "Everything forgotten mingles with what has been forgotten of the prehistoric world, forms countless, uncertain, changing compounds, yielding a constant flow of new, strange products." 135 It is as if the forward movement of history brings with it nothing but the perversion of the past, as if this movement constitutes progress. "My station up there is much too high," the parable goes, so a new Tower of Babel must be built underground, finding the Archimedean point in the depths; rather than the Chinese desire to find transcendence in the high command's decrees, the burrower hopes to find it in himself. As Arendt notes, this is "an attempt to reduce all experiences, with the world as well as with other human beings, to experiences between man and himself." ${ }^{136}$ The burrower's Tower of Babel, in conjunction with the one to be built upon the Great Wall, illustrates the dual motions of modernity, inward towards the self and outward towards the universe.

The importance of process, illustrated here in the building process, is apparent in Kafka's own articulation of progress: "To believe in progress is not to believe that progress has already taken place. That would be no belief." ${ }^{137}$ For Kafka, progress is always deferred; like Benjamin's angel of history, his characters always turn their backs on progress, and witness only the "pile of ruins" towering up before them. This is not a choice

\footnotetext{
134 KCS 357

135 Benjamin 131

136 HC 254

137 Benjamin 130
} 
so much as it is an unrelenting force, driving humanity forward in a crash course towards ruination. Progress might be found if man could turn away from the past and look towards his own self-created future, but for Kafka, as for Benjamin, this is impossible. The process, the striving for a progress which will never be achieved, leaves him with nothing but the striving itself, a trial that is doomed to end in execution, with only the shame of it living on. 138 The swamp world's darkness is infinite and impenetrable. Kafka made this apparent with his testament, demanding that Brod burn all of his unpublished papers after his death. The inevitability of failure is also confirmed by the unfinished nature of most of his mature work: as Borges says, "Kafka did not complete his novels because it was essential that they be incomplete." 139 It is essential because it is the process, and not the product that matters for modern man, for finished products are immediately subsumed by the use-value they possess and consumed, fading into the continuously recycled circle of consumption. "The shift from the 'why' and 'what' to the 'how' implies that the actual objects of knowledge can no longer be things or eternal motions but must be processes..." 140

Kafka understood this, and while his characters may not be able to digest the inevitability of failure entirely, they feel its effects. Arendt also understands this, to a degree: “...so surely the world, fabricated by men and constituted according to human and not natural laws, will become again part of nature and will follow the law of ruin when man decides to become himself part of nature, a blind though accurate tool of natural laws, renouncing his supreme faculty of creating laws himself and even prescribing them to

\footnotetext{
138 Recall the famous last words of The Trial

139 Borges 74

140 HC 296
} 
nature." ${ }^{141}$ Arendt goes astray when she reads Kafka's works as an articulation of escape, an expression of hope. ${ }^{142}$ While Kafka, and his characters, never cease to struggle, they are aware of the futility of this battle, and in the end they always succumb to the prescribed endpoint of progress - that is, failure. Here we might recall Camus' essay in the Myth of Sisyphus, in which he declares the works of Kafka to lack the true quality of the absurd, precisely because they contain hope. At the "vehement proceedings Kafka institutes against the whole universe... His unbelievable verdict is this hideous and upsetting world in which the very moles dare to hope." 143 This hope stems from the fact that they "embrace the God that consumes them," and through this embrace "the absurd is recognized, accepted, and man is resigned to it , but from then on we know that it has ceased to be the absurd." ${ }^{144}$ For Camus, following the vastly influential reading of Kafka by Brod, the motivation of the stories is religious, and where there is a God - even if it is a deus absconditus, a God who has turned his back on humanity - there is hope. The truly absurd work denies the existence of God and places man in a world with no recourse.

Camus' point is well-taken, but Kafka's God, I would argue, is thoroughly grounded in fragile human experience, subject to the same irrevocable forces as the population. This is no traditional God, guiding mankind and judging him omnisciently. Recall the "nature Gods" the Chinese worship in the home, a rite of prayer which is as scrutinized by the high command as the wall-building. Kafka's God offers no hope: "our world is only a bad mood

\footnotetext{
141 KAR 74

142 see the introduction, above

143 Camus 138

144 Camus 135
} 
of God, a bad day of his." 145 This is a thoroughly modern God, one who has abandoned his world to the laws of history, or at least subjected himself to them. The high command and the whistling entity both take the form of this inhuman law. We may wish to know them, to feel them or to be certain of their makeup, but we can only react to their residues. "I have reached the stage where I no longer wish to have certainty," 146 the burrower says after a long and arduous effort to discover the source of the whistling; he is now content to accept it for what it is, an incomprehensible mystery, and to subject himself to its inevitability. Likewise the narrator of "The Great Wall" cuts off his inquiry at the point where it might undermine the Chinese people's sense of assurance, not daring to peer into the nothingness at the heart of the high command. He approaches this point when he considers the "existent Emperor, a man like us, [who] lies much like us on a couch which is of generous proportions, perhaps, and yet very possibly may be quite narrow and short." 147 That "yet" contains a galaxy of meaning, the promise of a doubt which might tear the whole structure down and relieve the Chinese of their persistent hope for the emperor's touch, their trust in an opaque authority, and reassert their own collective agency. But it is still too vague, too distant: "But how should we know anything about that - thousands of miles away in the south - almost on the borders of the Tibetan Highlands? And besides, any tidings, even if they did reach us, would arrive far too late, would have become obsolete long before they reached us." 148 The vast landscape of China does not allow for truth. The burrower, with his Archimedean point progressing endlessly inward, cannot receive it either. The image

145 Benjamin 116

146 KCS 358

147 KCS 243

148 KCS 243 
here is that of a beam of light, racing towards an object across an expanding universe that recedes from the beam at an impossibly fast rate, while the inquisitive subject cannot see beyond the cosmic walls that enclose him.

This metaphor is not used indiscriminately. Kafka's world is uncannily similar to the one described by physics, without ever resorting to the symbolic language of mathematics. "The modern astrophysical world view," Arendt writes, "and its challenge to the adequacy of the senses to reveal reality, have left us with a universe of whose qualities we know no more than the way they affect our measuring instruments, and - in the words of Eddington - 'the former have as much resemblance to the latter as a telephone number has to a subscriber."' 149 Benjamin also cites a passage from Eddington's The Nature of the Physical World, an excerpt which he claims "bears the Kafka stamp" more clearly than any in literature:

I am standing on the threshold about to enter a room. It is a complicated business. In the first place I must shove against an atmosphere with a force of fourteen pounds on every square inch of my body. I must make sure of landing on a plank traveling at twenty miles a second around the sun - a fraction of a second too early or too late, the plank would be miles away. I must do this whilst hanging from a round planet head outward into space, and with a wind of aether blowing at no one knows how many miles a second through every interstice of my body. The plank has no solidity of substance. To step on it is like stepping on a swarm of flies. Shall I not slip through? No, if I make the venture one of the flies hits me and gives a boost up again; I fall

${ }^{149}$ HC 261 
again and am knocked upward by another fly; and so on. I may hope that the net result will be that I remain about steady; but if unfortunately I should slip through the floor or be boosted too violently up to the ceiling, the occurrence would be, not a violation of the laws of Nature, but a rare coincidence. Verily, it is easier for a camel to pass through the eye of a needle than for a scientific man to pass through a door. ${ }^{150}$

Kafka's men (and his animals) are the same scientific beings Eddington describes. For them, the most quotidian and arbitrary tasks of daily life take on a difficulty of Olympic proportions. In a different short story, Poseidon is assigned the endless, tedious work of "administration of all the waters," a task he does not like but must fulfill because it is "very difficult to find him another job." ${ }^{151}$ In Kafka's world, the great Greek deity has become a functionary. So it goes both ways; the quotidian is elevated to the Godlike, and the Godlike diminished to the mundane labor of the clerk. In a modern world where true descriptions must take the form of cold, impersonal calculations, and the same rules apply to the both atoms in the stomach and atoms in a star, everything is experienced as a well-oiled machine and the human subject is a mere cog in its precise movements. The Chinese people, educated in masonry and that alone, must view their world through the wall because only through the wall can variegated human experience become reified and comprehensible. "... the building of the wall in particular, with its abundance of human material, provided a man of sensibility with the opportunity of traversing the souls of

150 Benjamin 142

151 KCS 434 
almost all the provinces..." 152 "Human material"; this kind of formulation is only possible in the modern world. The burrower also, convinced that it is only through negligence and a poor work-ethic that perfect security has not been achieved, views the world as a machine, one which only needs endless fine-tuning to function flawlessly. He operates like Eddington's "scientific man," unable to act due to the overwhelming complexity of forces stacked against him. If he does manage to act it is because he momentarily loses himself: "And then, too exhausted to be any longer capable of thought, my head hanging, my legs trembling with fatigue, half asleep, feeling my way rather than walking, I approach the entrance..." 153 Whether passing through a door or re-entering a burrow, action really only requires thoughtlessness, for to consider the full implications of such a monumental task is impossible. And a thoughtless act is no different than the action of a machine.

Kafka's scientific characters also experience the modern distortion of space and time, in a very strange and real way. In "A Common Confusion" two characters try to set up a meeting, but always pass each other in transit; one leg of the journey takes ten minutes, the next day the same journey takes ten hours, and the next it takes ten seconds. At the end of it all, on the verge of finally meeting, one character twists his ankle and writhes in pain on the floor, while the other tromps past him "in a violent rage" and "vanish[es] for good." ${ }^{154}$ Arendt considers this story "the model of confusion itself," 155 and if we're willing to get a little abstract, it's the kind of confusion one encounters everywhere in a world governed by

\footnotetext{
152 KCS 247

153 KCS 341

154 KCS 429

155 KAR 78
} 
Einstein's laws of relativity. ${ }^{156}$ The monumental impact of Einstein's discovery (which was only verified thanks to the telescope) on modernity is well-documented. Everywhere the implication of relativism, in physical as well as moral or epistemological spheres, has made itself felt. One of Kafka's most singular achievements was to take these effects and concretize them, to make them felt rather than just known. Adorno claims Kafka "studies what would happen if the results of psychoanalysis were to prove true not merely metaphorically but in the flesh;" 157 we could easily replace "psychoanalysis" with "physics" without losing the glimmer of truth. While normal men go through doorways, build homes, and follow orders all the time, Kafka shows us just how unbelievably complex, and - one is tempted to say - impossible these tasks really are in the modern world. In the parable "An Imperial Message," placed near the end of "The Great Wall," the emperor's messenger travels with a message "to you, the humble subject, the insignificant shadow cowering in the remotest distance before the imperial sun." ${ }^{158}$ Yet no matter how fast he runs, how easily the way is cleared for him, he is unable to leave the "chambers of the innermost palace," "nobody could fight his way through here even with a message from a dead man." ${ }^{159}$ In astrophysical terms, the villager who dreams of the message at his window is the edge of the universe, the ultimate limit of man's sensory capabilities, racing away from the space it encloses faster than the speed of light.

How can one gain access to truth in such a world? The uncomfortable fact of the matter is that, in the modern world, truth is no longer a universal prospect. Arendt quotes

\footnotetext{
${ }^{156}$ For a fascinating essay on the relationship (personal and intellectual) between Kafka and Einstein, see Franz Kuna, "Rage for Verification."

157 Adorno 251

158 KCS 244

159 KCS 244
} 
Werner Heisenberg, the scientist who discovered the Uncertainty Principle: "Man in his hunt for 'objective reality' suddenly discovered that he always 'confronts himself alone."' 160 By finding the inherent limitations in man's acquisition of knowledge, Heisenberg stands with Einstein at the vanguard of the modern age. ${ }^{161}$ The impossibility of truly objective information does not decrease man's desire for it, hence the persistent dream of finding the Archimedean point, of overcoming the limitations and gaining certainty. Arendt and Heisenberg recognize that this desire inevitably leads back in towards the self, and it is here that "the humanist's concern with man and the stature of man has caught up with the scientist." 162 Kafka, who was no scientist, ${ }^{163}$ saw the convergence and articulated it with unsurpassed precision. The burrower is just one of the characters who recognizes the limits of what he can know, but the insight comes too late. Beset by his worst fear, an enemy who has no definite location and seems to emanate from everywhere at once, he finally understands that certainty brings no comfort; ${ }^{164}$ prior to this, his every activity is motivated by the desire to know and control everything. "But if my hypothesis does not meet the case, what can the explanation be?" 165 This is an exclusively modern question, as Arendt knows: "scientists formulate their hypotheses to arrange their experiments and then use these experiments to verify their hypotheses; during this whole enterprise, they

\footnotetext{
160 BPAF 277

161 The Uncertainty Principle, in very simple terms, states: "Increasing the accuracy of measurement of one observable quantity increases the uncertainty with which another conjugate quantity may be known." American Heritage Dictionary

162 BPAF 277

163 Though he did attend may scientific lectures and spoke with eminent physicists during Brod's literary meetings.

164 "I have had enough of discoveries; I let everything slide; I would be quite content if I could only still the conflict going on within me." KCS 352

165 KCS 345
} 
obviously deal with a hypothetical nature." 166 What's lost in this circular endeavor is any sense of a common world, interwoven through each person's connection to man-made things and every other human being. The burrower's insistence on testing his reality through endless experiments obviously does not require the presence of others, because his "truth" is situated somewhere within the private circle of the hypothesis-reality framework. For the Chinese wall-builders truth is somewhere "out there," at the top of a Tower of Babel which man will not be permitted to ascend, while their only connection to the world itself - the Great Wall - is sensible solely from this Archimedean point. Again, the loss of a common world is manifest in this kind of "reality." For the Chinese no less than the burrower the sense of reality comes from within, from an individual sense which fails to extend its perceptive circle beyond the individual mind and body.

For common sense, which once had been the one by which all other senses, with their intimately private sensations, were fitted into the common world, just as vision fitted man into the visible world, now became an inner faculty without any world relationship. ${ }^{167}$

To return to Kafka's notion of progress (or lack thereof) in the modern world, we may finally note that this Archimedean point, simultaneously extending out into the universe and back in towards the subject, is used against us by precisely this elimination of the common, public world. Arendt notes that the historical genesis of modernity, the French Revolution, began with the promise of just this kind of world. The French public post-1789 had become 'challengers,' had taken the initiative upon themselves and

166 HC 287

167 HC 283 
therefore, without knowing or even noticing it, had begun to create the public space between themselves where freedom could appear." 168 This dream, however, quickly and emphatically faded, and what was left was a world without tradition or memory, stuck in between a past composed of ruins and a future that seemed to follow inhuman laws. Freedom had lived briefly and brightly, but with its disappearance there went the possibility of meaningful action. Arendt quotes Tocqueville: "Since the past has ceased to throw its light upon the future, the mind of man wanders in obscurity." 169

Arendt uses Kafka's parable "He" to expand upon Tocqueville:

He has two antagonists: the first presses him from behind, from the origin. The second blocks the road ahead. He gives battle to both. To be sure, the first supports him in his fight with the second, for he wants to push him forward, and in the same way the second supports him in his fight with the first, since he drives him back. But it is only theoretically so. For it is not only the two antagonists who are there, but he himself as well, and who really know his intentions? His dream, though, is that some time in an unguarded moment - and this would require a night darker than any night has ever been yet - he will jump out of the fighting line and be promoted, on account of his experience in fighting, to the position of umpire over his antagonists in their fight with each other. ${ }^{170}$

What is most notable here is the dream, to remove oneself from the battling forces of history and to observe them objectively. Obviously what he desires is the Archimedean 
point. One could imagine Benjamin's angel of history with a similar wish, to once close his wings and feel the winds subside. But of course this, like the dream of perfect security and the emperor's message, is only a dream. The opposing historical forces have him firmly ensconced in a battle which effectively cancels itself out, holding the subject in a state of suspension. Everything we have discussed up to this point - the conflation of public and private, labor and work, the dream of the Archimedean point, operates along an invisible trajectory towards this goal. The result is a humanity composed of automatons, going through the requisite process of living and then dying of exhaustion, like K. in The Castle or Gregor Samsa in The Metamorphosis. Arendt sees a lesson in Kafka's parable, an exhortation towards thinking; only through the application of "thinking what we do" can we find a "diagonal line" which leads us to "the place in time which is sufficiently removed from past and future to offer 'the umpire' a position from which to judge the forces fighting with each other with an impartial eye." 171

In other words, there is a hope, and while it will require the most strenuous thought we can muster, it can lead us out of the impasse. While Arendt doesn't claim Kafka's shares her conviction, I believe she fails to understand him. Benjamin, on the other hand, is more faithful to the text. Once he was certain of eventual failure, everything worked out for him en route as in a dream." ${ }^{172}$ Kafka, unlike Arendt, accepts failure and works under its conditions, with the profound understanding that this is really the only way to work. It is not all morbid pessimism, however, for somewhere in this endless struggle little spaces for happiness, humor, and serenity open up. But the human, and the human condition, seems

171 BPAF 12

172 Benjamin 145 
unalterably doomed. The implications of Kafka's worldview, as both Arendt and Benjamin knew, would soon make themselves felt in reality: “Kafka's world, frequently of such playfulness and interlaced with angels, is the exact complement of his era which is preparing to do away with the inhabitants of this planet on a considerable scale." 173 Benjamin, who did not live to see the full horrors of the Holocaust, is referencing World War 1, but the "progress" made from former to latter is endemic of modernity. This is what Arendt means by claiming Kafka as a builder of "blueprints": he recognized that certain conditions could lead only to endless repetition, an eternal recurrence from which no escape is possible. In the office of the high command "one may be certain that all human thoughts and desires revolved in a circle, and all human aims and fulfillments revolved in a countercircle. And through the window the reflected splendors of divine worlds fell on the hands of the leaders as they traced their plans." ${ }^{174}$ All thought is already stuck in the circle, already assimilated into the impenetrable decrees of an ethereal authority. “...in absolute subjective space and absolute subjective time there is no room for anything that might disturb their intrinsic principle, that of inexorable estrangement," ${ }^{175}$ Adorno writes. The absolute and the inexorable; the subjective and the estranged. These seemingly contradictory terms are in some ways the operative terms of the modern age, the walls over which the modern human cannot see. The Archimedean point offers a ladder rising above the fray, but one can never climb it quickly enough. Yet he tries and tries again, and this trial is, for Kafka, the zero-sum of modern existence.

\footnotetext{
173 Benjamin 143

174 KCS 240
}

175 Adorno 261 


\section{Bibliography}

Adorno, Theodor W. Prisms. 5th. Cambridge: MIT Press, 1990. Print.

Arendt, Hannah. Between Past and Future. 9th. New York: Penguin Books, 1993. Print.

----- "Franz Kafka: A Revaluation." Partisan Review. 11.4 (1944): n. page. Print.

-----. The Human Condition. Chicago: University of Chicago Press, 1998. Print.

Benjamin, Walter. Illuminations. New York: Schocken Books, 1968. 111-145. Print.

Borges, Jorge Luis. Labyrinths. 10th. New York: New Directions, 1964. Print.

Boulby, Mark. "Kafka's End: A Reassessment of the Burrow." German Quarterly. 55.2 (1982): 175-185. Print.

Camus, Albert. The Myth of Sisyphus. New York: Vintage International, 1991. Print.

Corngold, Stanley. Lambent Traces: Franz Kafka. Princeton: Princeton University Press, 2004. Print.

Danoff, Brian. "Arendt, Kafka, and the Nature of Totalitarianism." Perspectives of Political Science. 29.4 (2011): 211-219. Print.

Disch, Lisa. "More Truth Than Fact: Storytelling as Critical Understanding in the Writings of Hannah Arendt." Political Theory. 21.4 (1993): 665-694. Web. 18 Mar. 2013.

Dossa, Shiraz. The Public Realm and the Public Self: The Political Theory of Hannah Arendt. Waterloo: Wilfrid Laurier University Press, 1989. Print.

Edwards, Ivana. "The Essence of "Kafkaesque"." New York Times [New York] 2912 1991. Web. 18 Mar. 2013.

Henel, Heinrich. "Kafka's Der Bau, or How to Escape from a Maze." Trans. Array The Discontinuous Tradition. Peter F. Ganz. Oxford: Clarendon Press, 1971. 224246. Print.

Kafka, Franz. The Complete Stories. New York: Schocken Books, 1971. Print.

----. Diaries. New York: Schocken Books, 1988. Print.

----. Parables and Paradoxes. 9th. New York: Schocken Books, 1974. Print. 
Kant, Immanuel. "An Answer to the Question "What is Enlightenment?"." . Philosophy on the EServer, 3009 1784. Web. 18 Mar 2013.

Kuna, Franz. "Rage for Verification: Kafka and Einstein." Trans. Array On Kafka: Semi Centenary Perspectives. Franz Kuna. London: Elek Books Ltd, 1976. 83-111. Print.

Maché, Britta. "The Noise in the Burrow: Kafka's Final Dilemma." German Quarterly. 55.4 (1982): 526-540. Print.

Morse, J. Mitchell. "Veblen, Kafka, Vico, and the Great Wall of China." Yale Review. 88.3 (2000): 101-110. Web. 18 Mar. 2013.

Penny, Laura. "Parables and Politics: How Benjamin and Deleuze \& Guattari Read Kafka." Theory and Event. 12.3 (2009): n. page. Web. 18 Mar. 2013.

Politzer, Heinz. Franz Kafka: Parable and Paradox. New York: Cornell University Press, 1962. Print.

Sokel, Walter. The Myth of Power and the Self. Detroit: Wayne State University Press, 2002. Print.

Thorlby, Anthony. "Anti-Mimesis: Kafka and Wittgenstein." Trans. Array On Kafka: Semi Centenary Perspectives. Franz Kuna. London: Elek Books Ltd, 1976. 5982. Print.

Wagenbach, Klaus. Kafka. London: Haus Publishing Ltd, 2002. Print.

Weigand, Hermann. "Franz Kafka's "The Burrow": An Analytical Essay." PMLA. 87.2 (1972): 152-166. Web. 18 Mar. 2013. 